\title{
Exploitation of Opuntia cactus by Birds on the Galápagos
}

\author{
B.R. Grant and P.R. Grant \\ Division of Biological Sciences, University of Michigan, Ann Arbor, Michigan 48109, USA
}

Summary. (1) There is a close association between Opuntia helleri (cactus) and Geospiza conirostris (cactus finch) on Isla Genovesa, and between Opuntia echios and Geospiza scandens on Isla Daphne Major. The two finch species consume nectar and pollen, pollinate the obligatorily out-crossing flowers, consume the aril around the seeds, crack the seeds and occasionally disperse them.

(2) In the dry season the two finch species open Opuntia flower buds, thereby gaining early access to pollen. But in the process, and at partially open flowers, they snip the style and destroy the stigmas in up to $78 \%$ of the flowers.

(3) Stigma snipping prevents fertilization of the ovules and the development of seeds which are an important food item later in the year when food supply is likely to limit finch population sizes. Stigma snipping almost ceases in the main part of the wet season, corresponding with an increase in the density of Opuntia flowers and other food types, and a decrease in the proportion of feeding time spent on Opuntia flowers. Stigma snipping neither increased the time flowers remained open nor influenced nectar flow or the number and duration of subsequent visits to flowers by potential pollinators. This last result precludes the possibility that snipping is a means of marking the flower to signal a previous visit to the flower and pollen removal.

(4) We conclude that the two finch species snip stigmas to facilitate removal of pollen from the central incurving stamens which are masked by the stigma in a closed or partially open flower. The finches gain a short-term benefit from the removal of stigmas in easy access to pollen and possibly nectar. They potentially suffer in the long term through diminished dry season food supply (seeds), particularly in drought years but we were unable to detect any fitness decrement suffered by the individual finches which do the snipping.

(5) An important implication of these results and interpretations is that a behavioral trait which confers a short-term benefit to the individual may increase the chances of the population going extinct.

\section{Introduction}

The adaptive radiation of Darwin's finches is well known (Lack 1947; Bowman 1963), and plausible inferences have been made about how it occurred (Lack 1945, 1947). Two of the finch species, Geospiza scandens and Geospiza conirostris are cactus specialists, and other finch species are known to visit cactus flowers (Lack 1945) and crack the seeds (Bowman 1961). In contrast, the adaptive radiation of Opuntia on the Galápagos
(Wiggins and Porter 1971) is less well known. Five species and several subspecies have radiated from possibly two ancestral stocks (Dawson 1962, 1965). The principal diversification is in seed size, in the degree of spinyness, and in growth form, which ranges from low shrubs to $10 \mathrm{~m}$ trees (Dawson 1962). Herbivore pressure from land iguanas and tortoises has been invoked to explain some of the variation in the last two features (Dawson 1966; Racine and Downhower 1974), but the evolutionary role of those herbivores is debated (Arp 1971). Other contributing factors are density and diversity of other plant species, light and wind (Arp 1971; Racine and Downhower 1974).

Our concern here is with the interaction of Opuntia cactus and finches. Lack $(1945,1947)$ and Bowman $(1961,1963)$ have already pointed out that the two cactus finches have relatively long and slender bills adapted for probing into flowers for nectar and pollen. Our previous studies have demonstrated the strong dependence of the two finch species upon Opuntia for food (Abbott et al. 1977; B.R. Grant and P.R. Grant 1979; Grant and Grant 1980a; Smith et al. 1978). They have also shown that these finches feed on the soft aril surrounding the seeds in the dry season and, in the case of $G$. scandens, also crack the seeds and extract the kernels. Therefore we were surprised to observe first $G$. scandens on Isla Daphne, then $G$. conirostris on Isla Genovesa, remove the stigmas of Opuntia flowers by snipping them at their point of attachment to the style (Fig. 1). This behavior is apparently maladaptive, in that it suggests the birds reduce seed set and hence the potential supply of a food which is exploited intensively in the dry season when food is limiting (Smith et al. 1978; Grant and Grant 1980a).

In this paper we report the results of an investigation into the role of these finches and other bird species in the pollination and seed production of Opuntia, the enigma of stigma snipping being the principal phenomenon to be explained. Our investigation is mainly confined to G. scandens and Opuntia echios on Daphne and $G$. conirostris and Opuntia helleri on Genovesa, although stigma snipping is more widespread, and we have evidence of it occurring in Opuntia on Islas Santa Cruz, Baltra, Pinta and Wolf.

\section{Methods}

We stayed on Isla Daphne Major from 23 November 1977 to January 5, 1978, and on Isla Genovesa from 19 January to 2nd May 1978 except for 3-5 April when we visited Isla Wolf. We also visited Isla Pinta 6-17 January 1978. One of us (P.R.G) returned to Isla Genovesa 10-26 November 1978 and 14-26 February 1980. We revisited Isla Genovesa 24 June-6 August 1979 and 23 June-27 July 1980, Isla 


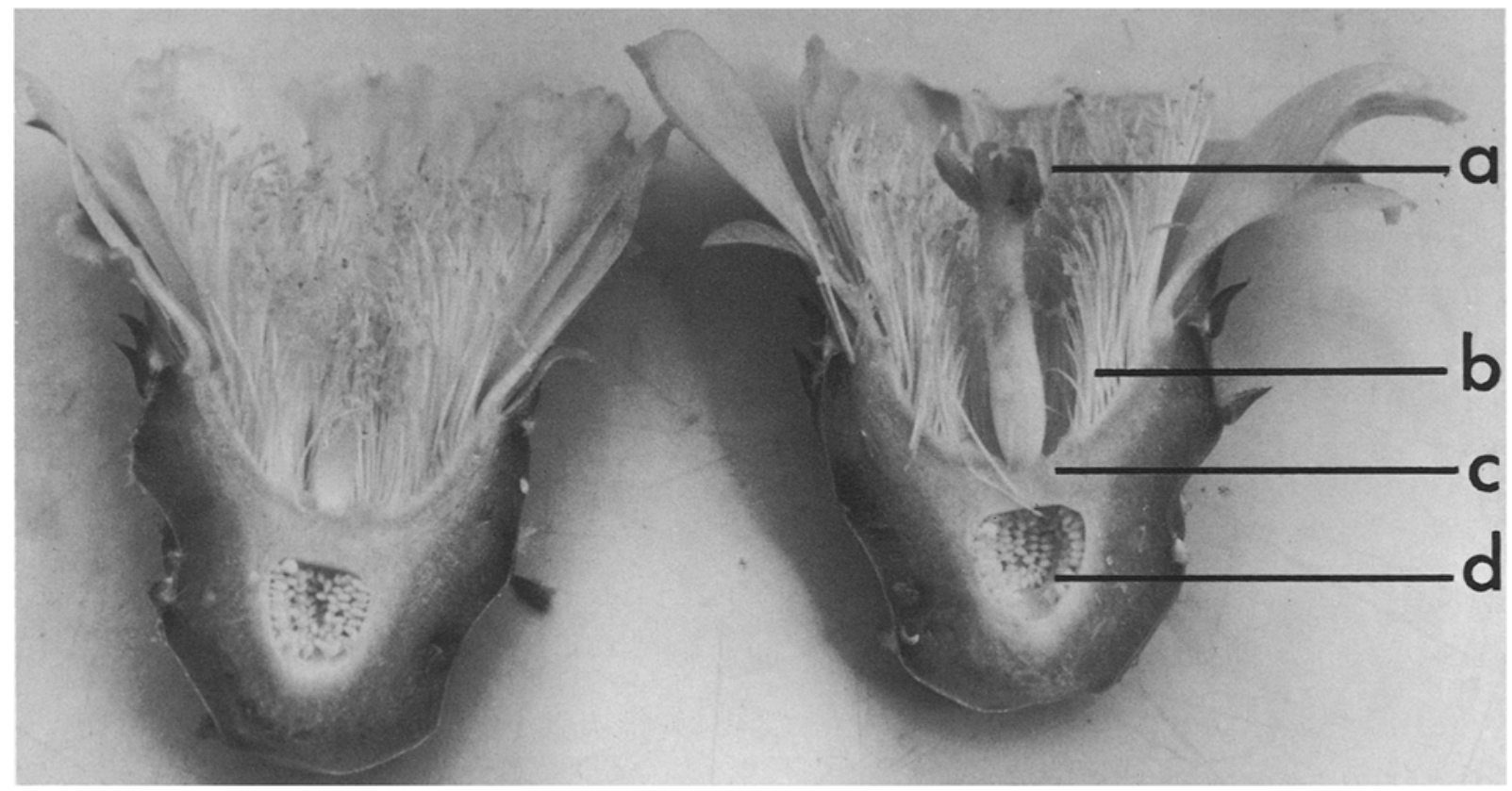

Fig. 1a-d. Vertical section through an open flower of Opuntia helleri. Note the various rows of filaments of different heights; time-lapse photography of an opening flower of $O$. echios showed that the filaments straighten out and lift upwards in at least eight concentric rings, starting from the outside and progressing inwards. Symbols: a stigmas, $\mathbf{b}$ inner short stamens, $\mathbf{c}$ spongy netar pad, $\mathbf{d}$ ovules

Española (Gardner Bay) 9-24 August 1979, and Isla Daphne 28 July5 August 1980.

The characteristics of the islands and our methods of sampling food availability and finch feeding have been described in Abbott et al. (1977), Smith et al. (1978), and Grant and Grant (1980a). In addition we investigated the role of birds as pollinators on Genovesa in February to March 1978 by covering Opuntia helleri buds with transparent plastic peanut butter jars with 5 holes of $1 \mathrm{~cm}$ cut at the distal end. These holes allowed insects access to the flowers but prevented birds from reaching the flowers. We removed jars 2-3 days after flowers had withered, and opened fruits $2-3$ weeks later when seed set could easily be determined. Controls were a) 12 flowers labelled with flagging after finches had been observed feeding but had left the stigmas intact and b) 10 flowers covered with jars and hand pollinated with pollen taken from flowers over $200 \mathrm{~m}$ away. We could not devise a reciprocal experiment allowing birds but not insects access to the pollen. To test the role of hawk moths as pollinators we repeated the experiment but removed the jars after sunset and replaced them before sunrise. There are no bats on Genovesa or Daphne (Orr 1966).

We estimated the proportion of Opuntia echios flowers snipped on Daphne between 16 December 1977 and 4 January 1978 by counting on successive days at $1,300 \mathrm{~h}$ all flowers on 61 bushes, and by noting the state of the stigmas. On Genovesa we counted Opuntia helleri flowers on 22nd January 1978 at $1,300 \mathrm{~h}$ on 15 bushes and thereafter on 5 bushes at weekly intervals from 22 January to 1 May 1978. Flowers on the same 5 bushes were counted in July 1979.

We investigated the effect of stigma snipping on the fertilization of Opuntia echios. On 15-18 December 1977 on Daphne between 0,700 and $0,900 \mathrm{~h}$ we watched individuals of $G$. scandens open buds and remove the stigmas from the flowers on 14 bushes. On each of these bushes we opened 2 other buds by hand, snipped the style of one with scissors and left the other with stigmas and style intact. Buds were labelled with flagging tape. Of the resulting 14 bushes with 3 labelled buds, 4 bushes either lost one of the labels or the bud or fruit fell off; these bushes were not used for the results. Fruits were opened 16-18 days later and examined for seeds. The procedure on Genovesa was simpler; 67 open flowers of Opuntia helleri, including 23 with stigmas removed by $G$. conirostris, were labelled at $1,300 \mathrm{~h}$ between
26-28 January 1978 . We opened 63 fruits 2-3 weeks later and counted the seeds.

We made 3 all day $(0,600-1,815 \mathrm{~h})$ observations of Opuntia flowers. Two all day watches of Opuntia echios flowers were done on Daphne; 17 flowers on December 19, 1977 and 23 flowers on December 21 1977. On Genovesa we observed visits to 42 Opuntia helleri flowers on January 30,1978 . Observers alternated every $2 \mathrm{~h}$. We recorded the time of flower opening, state of stigma and time and duration of all visits to individual flowers.

To find the concentration and time of production of nectar in Opuntia helleri flowers on Genovesa, we bagged 17 buds on 15 different bushes in June 1980. We visited them at least once an hour when they were expected to open, then attempted to withdraw nectar from them at $0,700-0,830 \mathrm{~h}, 1,130-1,400 \mathrm{~h}$ and $1,730-1,800 \mathrm{~h}$. We used a $1 \mathrm{ml}$ syringe and determined the nectar sugar in sucrose equivalence in $\mathrm{g}$ solute per $100 \mathrm{~g}$ solution with an Ermo ${ }^{\circledR}$ refractometer.

To test the hypothesis that flowers produce more nectar, as a result of stigma removal, we experimented with 12 flowers on 3 Opuntia helleri bushes (4 flowers/bush) on Genovesa, 23 February 1980. We withdrew the nectar and measured the sugar concentration in early afternoon; we then snipped the stigmas with scissors in half of the flowers on each bush and covered the flowers with cheesecloth bags; $21 / 2 \mathrm{~h}$ later we withdrew nectar from the flowers and determined the sugar concentration.

To determine the length of time flowers with stigmas intact and with stigmas snipped remained open, we labelled 79 flower buds of Opuntia helleri on Genovesa in July 1979. These were visited three times daily. We were thus able to measure the length of time a flower remained open to the nearest half day.

To find a difference, if any, in seed set between flowers pollinated nearby or at a distance, we hand pollinated flowers of Opuntia helleri on Genovesa in July 1979. Buds were covered with cheesecloth bags and examined daily. When flowers opened we used a Johnson ${ }^{\circledR}$ cotton bud for each pollination and discarded it after use. Flowers were pollinated with pollen brought from flowers at a distance of $>200 \mathrm{~m}$ $150 \mathrm{~m}, 50 \mathrm{~m}, 5 \mathrm{~m}$, bushes in the same cactus spread, the same bush and from the same flower. A spread is composed of several bushes growing closely together. Adjacent bushes often grow vegetatively from 
pads of their neighbors that fall to the ground, so it is probable that many bushes within a spread are genetically related.

\section{Results}

We first describe the phenology of Opunita, the various ways in which it is exploited for food by birds and how it is pollinated, and then present quantitative data on stigma removal and its consequences to both cactus and birds.

Opuntia Phenology. Opuntia flowers have been recorded by us or by an assistant on Genovesa in all months of the year except September (no visits to the island then). However flowering is largely concentrated in the months November to February (Daphne) or November to April (Genovesa); and only an occasional flower was open on Daphne in March to June 1979 (T.D. Price pers. comm.). The rainy season normally extends from January to April or May (Grant and Boag 1980), therefore flowering spans both the late dry season and the wet season (Grant and Grant 1980a).

Each bush produces a few flowers everyday throughout the flowering season. Although we did not systematically quantify the complete flowering season of individual bushes, we know that 5 bushes had flowers open every day for three months, January to April 1978 on Genovesa. We counted flowers on these bushes once a week from 26 January to 19 April 1978. On average there were $11.6 \pm 1.8(\bar{x} \pm S E)$ flowers per bush with a peak in the third week of March, and the average volume of the bushes was $9.7 \pm 2.4 \mathrm{~m}^{3}$. M. Kinnaird counted flowers for us on 10 bushes over the same period in 1980 . There were $15.0 \pm 2.8$ flowers per bush, and the average bush size was $20.1 \pm$ $4.6 \mathrm{~m}^{3}$. Flowering peaked in the fourth week of March.

Flowers open about three weeks after the buds begin to develop, usually in the morning, and stay open for $24-48 \mathrm{~h}$. The seeds take several months to mature, therefore the long flowering season translates into asynchrononous fruit ripening. Fruits fall off the pad asynchronously (see also Racine and Downhower 1974). Figure 2 shows the number of fruits remaining on two pads on an Opuntia echios tree at Bahía Academía, Santa Cruz. Fruits fell in all months of the year from 4 to 428 days $(\bar{x} 227.3 \pm S E 23.2)$ after flowering in December 1973 and January 1974 . The early falling fruits may not have contained seeds. On Genovesa we found ripe fruits on some bushes throughout the year and they were plentiful in June, July and November.

Opuntia as a Food Resource. Finches (Geospiza), doves (Zenaida) and mockingbirds (Nesomimus) feed on Opuntia. Table 1 lists the reproductive parts eaten by different species on different islands (see also Bowman and Carter 1970).

Nectar is taken apparently only by mockingbirds, by $G$. scandens, by $G$. conirostris on Genovesa and by $G$. difficilis on Wolf. These species have long and narrow bills. The nectar is present in a spongy pad around the base of the style (Fig. 1), and can be reached only by a deep probing motion. Nectar starts to collect above the pad about one hour after the flower begins to open, and production generally ceases after a further two hours. Of the 17 bagged flower buds, 16 subsequently opened and produced nectar. The total volume of nectar produced per flower was $0.11 \pm 0.02 \mathrm{ml}$, and the sugar concentration was $22.0 \pm 0.4 \%$ (g solute per $100 \mathrm{~g}$ solution). The concentration is within the normal range of bird-pollinated flowers (Baker 1975). Nectar was renewed in only one of the 16 flowers after it was withdrawn by us. Therefore nectar is available to a bird for probably a short time.

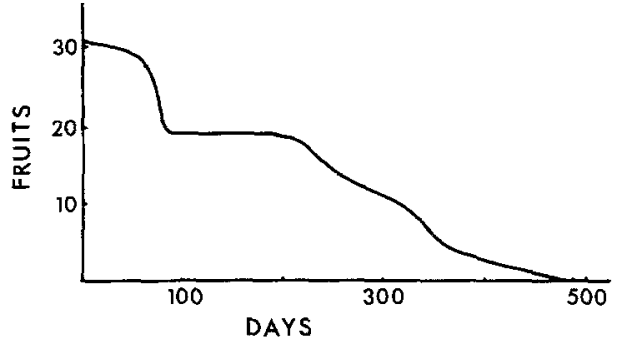

Fig. 2. The number of fruits remaining on two pads of an Opuntia echios tree at Bahía Academía, Isla Santa Cruz after the flowering period in December 1973 and January 1974. Survival on the pads was checked at two week intervals

The long-billed species also probe deeply into the flowers for the pollen in anthers on the short central stamens (Fig. 1). The other finch species do not probe into the flower but restrict their feeding to the more elevated anthers at the surface of the flower. The long-billed species feed from these also. Pollen is removed with tongue and bill. We know that pollen and not insects were eaten during foraging because we had a clear view of some flowers from as short a distance as two or three meters, and we have recorded close-up sequences of feeding on super-8 film. Furthermore large quantities of pollen occurred in nine per cent $(N=78)$ of $G$. conirostris nestling crops (Grant and Grant 1980a). Doves were exceptional in removing clusters of anthers by biting through the stamens, sometimes all the stamens in a flower, and they also ate the petals (P.R. Grant and K.T. Grant 1979).

In our 3 all-day observations at a total of 82 Opuntia flowers we found that all flowers were visited repeatedly by birds on both Genovesa and Daphne, and that most, if not all, of the pollen was removed. Similarly when we counted flowers to inspect the stigmas, we noticed by the absence of pollen and by the damage to the anthers that every flower had been visited except for the rare inaccessible flower i.e. a flower surrounded by pads.

The aril surrounding the seed was tested with Tes-Tape Lilly ${ }^{(3)}$ and found to contain glucose, as did the nectar. The aril is fleshy in $O$. echios, $O$. helleri and $O$. galapageia, but it is fibrous in $O$. megasperma. It is consumed by some bird species on four of the islands we visited (Table 1), and possibly on the other two islands which we visited briefly. Mockingbirds, $G$. scandens and $G$. conirostris use their beaks to hammer a hole in a ripe fruit, either on the plant or ground, and remove the seeds. The other species of finches, with blunter beaks, are apparently unable to open a fruit by themselves and are therefore dependent upon one of these three species for access to the seeds (e.g. see Grant and Grant 1980 a, Smith et al. 1978). Mockingbirds generally swallow the seeds and the aril is removed internally; then the seeds are either voided in feces or regurgitated whole. The finches remove the aril from the seed with the beak and discard the seed, although G. magnirostris on Genovesa occasionally crack them. Dry seeds are picked up from the ground or from fruits and cracked by $G$. magnirostris everywhere, but by $G$. fortis and $G$. scandens only on islands where the seeds are relatively small and soft. We have seen $G$. scandens on Daphne flying up to $50 \mathrm{~m}$ carrying dried Opuntia fruit cases before eating the seeds inside. On Española, where $G$. conirostris has a large bill, it cracks the large Opuntia seeds, but on Genovesa where it has a smaller bill we saw only two $G$. conirostris crack Opuntia seeds. Finally doves swallow seeds whole and crush them in the gizzard (P.R. Grant and K.T. Grant 1979). 
Table 1. Opuntia seed characteristics on six islands and the avian consumers of Opuntia flower parts and seeds. A composite index of size (depth) and hardness ( $\mathrm{kgf}$ ) of seeds has been taken from Abbott et al. (1977) or calculated by the same methods

\begin{tabular}{|c|c|c|c|c|c|c|}
\hline \multirow[t]{2}{*}{ Island } & \multirow[t]{2}{*}{ Opuntia species } & \multirow{2}{*}{$\begin{array}{l}\text { Average } \\
\text { size hardness } \\
\text { of seeds }\end{array}$} & \multicolumn{3}{|c|}{ Exploitation for food } & \multirow[t]{2}{*}{ Seed kernel } \\
\hline & & & Pollen & Nectar & Aril & \\
\hline Santa Cruz & O. echios & 2.27 & $\begin{array}{l}\text { G. fuliginosa } \\
G . \text { fortis } \\
G . \text { scandens }\end{array}$ & $\begin{array}{l}G . \text { scandens } \\
N . \text { parvulus }\end{array}$ & $\begin{array}{l}\text { G. fuliginosa } \\
G . \text { fortis } \\
G . \text { scandens }\end{array}$ & $\begin{array}{l}\text { G. fortis } \\
\text { G. scandens }\end{array}$ \\
\hline Daphne & O. echios & 2.79 & $\begin{array}{l}\text { G. fuliginosa } \\
\text { G. fortis } \\
\text { G. scandens } \\
\text { G. magnirostris }\end{array}$ & G. scandens & $\begin{array}{l}\text { G. fortis } \\
\text { G. scandens } \\
\text { G. magnirostris }\end{array}$ & $\begin{array}{l}\text { G. fortis } \\
\text { G. scandens } \\
\text { G. magnirostris }\end{array}$ \\
\hline Española & O. megasperma & $>10.90$ & $\begin{array}{l}\text { G. conirostris } \\
N . \text { macdonaldi }\end{array}$ & & $\begin{array}{l}\text { G. fuliginosa } \\
\text { G. conirostris } \\
\text { N. macdonaldi } \\
\text { Z. galapagoensis }\end{array}$ & G. conirostris \\
\hline Genovesa & O. helleri & 7.02 & $\begin{array}{l}\text { G. difficilis } \\
\text { G. conirostris } \\
\text { G. magnirostris } \\
\text { N. parvulus } \\
Z . \text { galapagoensis }\end{array}$ & $\begin{array}{l}G . \text { conirostris } \\
N . \text { parvulus }\end{array}$ & $\begin{array}{l}\text { G. difficilis } \\
\text { G. conirostris } \\
G . \text { magnirostris } \\
N . \text { parvulus }\end{array}$ & G. magnirostris \\
\hline Wolf & O. helleri & 6.83 & $\begin{array}{l}\text { G. difficilis } \\
\text { G. magnirostris } \\
\text { N. parvulus } \\
\text { Z. galapagoensis }\end{array}$ & & & \\
\hline Pinta & O. galapageia & 7.55 & $\begin{array}{l}\text { G. fuliginosa } \\
\text { G. fortis } \\
\text { G. scandens } \\
\text { N. parvulus }\end{array}$ & $\begin{array}{l}\text { G. scandens } \\
N . \text { parvulus }\end{array}$ & & G. magnirostris \\
\hline
\end{tabular}

Finches have been observed feeding on the nectar at the base of spine clusters (extrafloral nectaries) on all islands. Finches, doves and mockingbirds drink fluid, eat moist pulp and take insect larvae from damaged pads and trunks; G. scandens, $G$. conirostris and mockingbirds have been seen to cause the damage.

Table 2 suggests that nectar and pollen from flowers and either the kernel or aril from seeds form a substantial part of the food of $G$. scandens and $G$. conirostris at different times of the year (see also Abbott et al. 1977, Smith et al. 1978).

Pollination. In a pollination experiment on Santa Cruz, Rick (1966) found two O. echios flowers to be self-incompatible. We repeated the experiment with $O$. helleri on Genovesa and obtained a similar result (Table 3). Only 2 out of 10 flowers had seeds and then only 2 and 1 seed respectively. Flowers given pollen from other flowers on the same bush produced on average less than 4 seeds per fruit. Flowers given pollen from flowers on different bushes but in the same spread (defined in methods) did not produce significantly more seeds than flowers which had received pollen from the same flower or the same bush $\left(t_{18}=0.0, P>0.2 ; t_{18}=1.2, P>0.2\right)$. Flowers given pollen from others $5 \mathrm{~m}$ away but not in the same cactus spread produced significantly more seeds $\left(t_{18}=6.15, P<0.001\right)$. Flowers given pollen from flowers up to $200 \mathrm{~m}$ away produced significantly more seeds than those given pollen from flowers in the same spread $(P<0.001$ in all cases). Thus an effect of distance upon probability of fertilization is demonstrated (see also Table 3) but there is no systematic pattern over the 5 to $200 \mathrm{~m}$ range of distances. To check that the potential for fertilization was the same in all groups we performed a one way ANOVA on total number of ovules (fertilized and not fertilized) in the six groups studied at the same time (same flower, same bush, same spread, $5 \mathrm{~m}, 50 \mathrm{~m}$ and $>200 \mathrm{~m}$ ). The assumption of homogeneity was upheld; $F_{5,40}=1.75, P>0.1$.

Birds and insects are potential pollinators. On Daphne Opuntia echios flowers are visited by the carpenter bee Xylocopa darwini, four Geospiza species (Table 1) and a beetle (Ammophorus $\mathrm{sp}$ ). The carpenter bee has never been found on Genovesa. Here the flowers of $O$. helleri are visited by three species of finches, mockingbirds and doves (Table 1), by crickets, dipteran flies, an ant Tetramorium guineense (Fabr.) Wheeler and a hawkmoth Protoparce rustica galapagoensis Holland. In 1980, the caterpillar that feeds on Croton flowers was very abundant and many individuals were found in Opuntia flowers feeding on pollen. We did not observe this in 1978 .

Table 4 shows the results of an experiment to test the role of birds as pollinators of $O$. helleri on Genovesa. Only one of the 11 flowers covered by jars produced a fruit with seeds; and then only two seeds. Of 12 flowers not covered, 10 produced fruits with seeds and the mean number of seeds per fruit for all 12 was $27.8 \pm 9.6$. The proportions of flowers covered and uncovered which produced seeds were not equal (two tailed Fisher's Exact Text, $P<0.01$ ). Repeated checks on the flowers showed that both covered and not covered flowers had crickets, flies and ants in approximately equal frequency. Therefore arthropods could not be responsible for the difference in seed production. 
Table 2. Exploitation of Opuntia flowers by finches on Islas Genovesa and Daphne. Except for the incidence of stigma snipping and feeding data for July (1979 and 1980), the calculations are based on data in Grant and Grant (1980a, 1980 b). Observations were made in December 1977, January, February, April and November 1978, July 1979, and July 1980. The last column excludes species that spent less than one percent of foraging time on Opuntia flowers

\begin{tabular}{|c|c|c|c|c|c|c|}
\hline $\begin{array}{l}\text { Percent of Opuntia flowers } \\
\text { with stigmas snipped }\end{array}$ & $\begin{array}{l}\text { Relative density } \\
\text { of Opuntia flowers } \\
\text { Mean number of } \\
\text { flowers per day } \\
\text { on } 5 \text { bushes }\end{array}$ & $\begin{array}{l}\text { Proportion of } \\
\text { foraging time } \\
\text { spent opening } \\
\text { buds of Opuntia: } \\
\text { G. conirostris }\end{array}$ & $\begin{array}{l}\text { Proportion of } \\
\text { foraging time } \\
\text { spent on flowers } \\
\text { of Opuntia: } \\
\text { G. conirostris }\end{array}$ & $\begin{array}{l}\text { Proportion of } \\
\text { foraging time } \\
\text { spent on } \\
\text { Opuntia seeds } \\
\text { G. conirostris } \\
\text { arils only }\end{array}$ & $\begin{array}{l}\text { Number of } \\
\text { food items } \\
\text { (species) in } \\
\text { the diet of } \\
\text { G. conirostris }\end{array}$ & $\begin{array}{l}\text { Number of } \\
\text { other bird } \\
\text { species } \\
\text { foraging on } \\
\text { Opuntia } \\
\text { flowers }\end{array}$ \\
\hline
\end{tabular}

\section{Genovesa}

\begin{tabular}{|c|c|c|c|c|c|c|}
\hline January $78.1(N=128)$ & $8.4 \pm 2.58$ & 0.117 & 0.408 & 0 & 5 & 4 \\
\hline February $\quad 0.8(N=539)$ & $14.09 \pm 1.38$ & 0.019 & 0.176 & 0.025 & 10 & 1 \\
\hline July $\quad 70.6(N=68)$ & $0.4 \pm 0.22$ & 0.010 & 0.021 & 0.523 & 7 & 0 \\
\hline November $36.5(N=192)$ & & 0.131 & 0.287 & 0.250 & 4 & 2 \\
\hline $\begin{array}{l}\text { Percent of Opuntia flowers } \\
\text { with stigmas snipped }\end{array}$ & & $\begin{array}{l}\text { Proportion of } \\
\text { foraging time } \\
\text { spent opening } \\
\text { buds of } O_{\text {puntia }} \\
\text { G. scandens }\end{array}$ & $\begin{array}{l}\text { Proportion of } \\
\text { foraging time } \\
\text { spent on Opuntia } \\
\text { flowers and buds } \\
\text { G. scandens }\end{array}$ & $\begin{array}{l}\text { Proportion of } \\
\text { foraging time } \\
\text { spent on } \\
\text { Opuntia seeds } \\
\text { G. scandens } \\
\text { seeds and arils }\end{array}$ & $\begin{array}{l}\text { Number of } \\
\text { food items } \\
\text { (species) } \\
\text { in the diet } \\
\text { G. scandens }\end{array}$ & $\begin{array}{l}\text { Number of } \\
\text { other bird } \\
\text { species } \\
\text { foraging on } \\
\text { Opuntia } \\
\text { flowers }\end{array}$ \\
\hline \multicolumn{7}{|l|}{ I. Daphne } \\
\hline \multicolumn{2}{|l|}{ December $48.4 \quad(N=2193)$} & 0.298 & 0.561 & $\begin{array}{l}0.002 \\
0.441 \text { (March 1973) } \\
0.900 \text { (July 1980) }\end{array}$ & 4 & 2 \\
\hline
\end{tabular}

Table 3. Results of hand pollination experiments of Opuntia helleri on I. Genovesa, using pollen from different sources

\begin{tabular}{lcll}
\hline Source of pollen & $\begin{array}{l}\text { Number } \\
\text { of fruits } \\
\text { with } \\
\text { some seeds }\end{array}$ & $\begin{array}{l}\text { Number } \\
\text { of fruits } \\
\text { with }\end{array}$ & $\begin{array}{l}\bar{x} \pm \text { SE seeds } \\
\text { seeds } \\
\text { per fruit }\end{array}$ \\
\hline $\begin{array}{l}\text { Same flower } \\
\text { Another flower on same bush }\end{array}$ & 2 & 8 & $0.30 \pm 0.2$ \\
$\begin{array}{l}\text { Flower on another bush within } \\
\text { the same spread }\end{array}$ & 3 & 6 & $3.4 \pm 2.6$ \\
$\begin{array}{l}\text { Flower on adjacent bush } \\
<5 \mathrm{~m} \text { away }\end{array}$ & 4 & 7 & $0.3 \pm 0.2$ \\
$\begin{array}{l}\text { Flower on bush } 5 \mathrm{~m} \text { away } \\
\text { Flower on bush } 50 \mathrm{~m} \text { away }\end{array}$ & 9 & 1 & $1.8 \pm 3.4$ \\
Flower on bush $100 \mathrm{~m}$ away & 10 & 0 & $65.3 \pm 6.3$ \\
Flower on bush $150 \mathrm{~m}$ away & 10 & 0 & $91.8 \pm 12.7$ \\
Flower on bush $200 \mathrm{~m}$ away & 6 & 0 & $52.4 \pm 8.7$ \\
\hline
\end{tabular}

Hawkmoths visited flowers after sunset, although we never saw them visit a jar-covered flower and suspected that the jars excluded them. For this reason we repeated the experiment but removed the jars after sunset and replaced them before sunrise (Table 4). Hawkmoths were abundant and we saw six of these flowers visited by them within $30 \mathrm{~min}$ after sunset. None of the 10 flowers with covers removed at night produced fruits with seeds, whereas nine of the 10 controls produced seeds $(19.3 \pm 6.1$ seeds per fruit; two tailed Fisher's Exact Text, $P<0.01$ ). Therefore hawkmoths do not pollinate flowers of $O$. helleri on Genovesa.
Table 4. Results of experiments on I. Genovesa to determine if birds (daytime, experiment 1) and hawkmoths (night-time, experiment 2) pollinate flowers of Opuntia helleri: see text for further details

\begin{tabular}{lcc}
\hline & Control & $\begin{array}{c}\text { Experi- } \\
\text { mental }\end{array}$ \\
\hline Experiment 1. Flowers protected from birds for $24 \mathrm{~h}$ & \\
Number of fruits with some fertile ovules & 10 & 1 \\
Number of fruits with no fertile ovules & 2 & 10 \\
$\bar{x} \pm$ SE fertile ovules per fruit in total sample $27.8 \pm 9.6$ & 0.1 \\
\hline Experiment 2. Flowers protected from birds dawn to dusk \\
Number of fruits with some fertile ovules \\
Number of fruits with no fertile ovules
\end{tabular}

Since only one seed was produced from the group of jarcovered flowers, we hand pollinated 10 more jar-covered flowers with pollen from $>200 \mathrm{~m}$. All produced seeds; the mean number of seeds per fruit was $71.2 \pm 11.2$. This demonstrates that jars do not prevent fertilization, and we conclude that pollination by birds was responsible for the results in the previous two experiments.

Carpenter bees (Xylocopa darwini) are thought to be the main pollinators where they occur on the southern islands (Linsley 1966; Rick 1966). However, the result of a trial experiment on flowers of Opuntia echios at the Charles Darwin Research 
Station on Santa Cruz indicate that birds are additional pollinators. We covered five flowers with chicken wire that allowed bees but not birds, to enter the flowers. Five other flowers not covered were assigned as controls. The number of seeds produced per fruit was scored as less than 10 (few) or more than 10 (many). All five covered flowers produced few seeds and all five control flowers produced many. Therefore seed set was higher when both birds and bees had access to the flowers than when bees were the sole visitors (cf., Carpenter 1976). The difference in seed set appears to be attributable to the birds, although we cannot exclude the possibility that bees visited covered flowers less often than uncovered ones.

Stigma Snipping. The peak flower opening time on both Daphne and Genovesa was $0,900-1,100$ h. G. scandens on Daphne and $G$. conirostris on Genovesa attacked closed flower buds that were about to open by pulling apart the folded petals, particularly between 0,700 and $0,900 \mathrm{~h}$. Immediately after opening a flower bud the finch sometimes snipped the style at the base of the stigmas with its beak, and flicked the stigmas away. We observed stigma snipping after bud opening and at partially opened flowers. At open flowers the finches usually held the style to one side with a foot. Stigma removal presumably facilitates access to the pollen, particularly the pollen situated on the small central incurving anthers that would be masked by the stigma in the closed or partially opened flower (Fig. 1). Stigma snipping would also facilitate access to nectar, but it was sometimes performed so soon after the opening of the bud that it is doubtful if any nectar was present. Stigmas were snipped by a minimum of 12 adult individuals of $G$. scandens on Daphne and 11 adult $G$. conirostris on Genovesa. Both males and females were seen snipping stigmas.

Table 2 shows that stigma snipping was frequent in January but almost ceased in February to April. The decrease in snipping corresponded with a decrease in early morning bud opening by the finches, an increase in both the number of $O$ puntia flowers and appearance of alternative food items e.g. caterpillars, and a decrease in the proportion of feeding time spent on Opuntia flowers by all other bird species; for example the proportion of time spent feeding on Opuntia flowers by the doves $Z$. galapagoensis decreased from 0.848 in January to 0.012 in February to April. Later in July, stigma snipping increased. There were very few flowers available at this time. Thus stigmas were snipped when food was scarce and the proportion of time spent foraging on Opuntia flowers by all bird species was high.

Consequences of Stigma Snipping to Opuntia. To test the hypothesis that stigma snipping reduced seed set we followed the fates of (1) flowers with stigmas snipped by $G$. scandens, flowers with stigmas snipped by us with scissors and undamaged flowers on 14 bushes on Daphne and (2) undamaged flowers and flowers with stigmas snipped by $G$. conirostris on Genovesa.

Results of the experiment (1) on Daphne (Table 5) showed that stigma snipping by either $G$. scandens or scissors prevented fertilization of the ovules (two tailed Fisher's Exact Text $P$ $<0.005$ ). Stigma snipping by $G$. conirostris on Genovesa (2) had the same effect $\left(\chi^{2}=34.83, P<0.001\right)$. Further observation of flowers on Genovesa in July showed that flowers with stigmas removed early in the day before $1,000 \mathrm{~h}$ never produced seeds, but $21.4 \%$ of flowers that lost their stigmas after $1,300 \mathrm{~h}(N=14)$ produced fruits that contained some seeds. Fewer seeds were produced by these flowers $(6.3 \pm 4.8)$ than by 11 controls $(63.8 \pm$ 12.2). Therefore stigma snipping prevents fertilization but if pollen reaches a stigma before it is snipped there is a small chance that some ovules will be fertilized.
Table 5. Results of experiments to determine the effect of stigma removal upon seed set

\begin{tabular}{llll}
\hline Stigmas & Stigmas & Stigmas \\
removed & removed & left \\
by finch & by scissors & intact \\
after & after & (control) \\
opening & opening & \\
of bud & of bud & \\
\hline
\end{tabular}

Experiment 1. Opuntia echios affected by G. scandens on I. Daphne

\begin{tabular}{lccc}
$\begin{array}{l}\text { Number of fruits with at least } \\
\text { one fertile ovule }\end{array}$ & 0 & 0 & 9 \\
$\begin{array}{l}\text { Number of fruits with no } \\
\text { fertile ovules }\end{array}$ & 10 & 10 & 1 \\
$\begin{array}{l}\bar{x} \pm \text { SE fertile ovules per fruit } \\
\text { in total sample }\end{array}$ & 0 & 0 & $85.4 \pm 14.0$ \\
\hline
\end{tabular}

Experiment 2. Opuntia helleri affected by $G$. conirostris on I. Genovesa

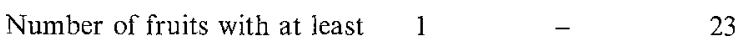
one fertile ovule

$\begin{array}{llll}\text { Number of fruits with no } & 26 & - & 6\end{array}$ fertile ovules

$\bar{x} \pm$ SE fertile ovules per fruit $\quad 0.04 \quad-\quad 32.8 \pm 5.5$ in total sample

We then estimated the effect of stigma snipping on subsequent seed production. Table 6 shows that the proportion of flowers with stigmas intact which were fertilized was approximately constant around $80 \%$ at all times. Knowing this, and the percentage of flowers with stigmas snipped, we estimated the percent of all flowers that yielded fruit containing some seeds. The percent varies from 17 to 81 . Stigma snipping is the major determinant of this variation. Effects of stigma snipping on overall mean number of seeds produced per flower are partly compensated for in July by higher seed set per fruit.

To test the hypothesis that stigma snipping causes the flower to increase nectar production or concentration, we withdrew as much nectar as possible from six control flowers and six experimentals from which we then removed the stigmas. The initial nectar concentrations in the two groups were similar $\left(t_{10}=\right.$ $0.29, P>0.1)$. Two and a half hours later the amount of nectar in flowers was so low that none could be obtained from three of the experimentals and one of the controls, and only a trace could be obtained from the remainder, and in these the sugar concentration had not changed. Possibly the traces of nectar obtained for determining concentrations at the end of the experiment were left over from the first withdrawals. No nectar was present the next day in either experimentals or controls. Therefore stigma snipping did not increase nectar production. Early stigma snipping could actually suppress or prevent nectar production, but we did not investigate this possibility.

Although seed set is reduced by stigma snipping, pollen collection and distribution may be enhanced if the flower stays open longer. Therefore we examined the duration of opening of flowers with or without stigmas snipped. We found that flowers with stigmas snipped at or before opening by $G$. conirostris stayed open a significantly shorter time than the controls $\left(t_{35}=3.96, P<0.001\right)$. The controls did not differ significantly from flowers that lost their stigmas by our manipulation early in the day or by $G$. conirostris activity later in the day $(P>0.1$ in each case). Therefore stigma snipping does not prolong the flowering period of individual flowers, rather it tends to shorten it. 
Table 6. Estimates of Opuntia seed production in different months, based partly on percent of flowers with stigmas snipped (see Table 2)

Percent of stigma intact $\quad \bar{x} \pm$ SE seeds per fertilized flowers fertilized flower with stigmas intact
Estimated percent of all Estimated $\bar{x}$ seeds flowers that yield fruit per flower for all with at least one seed flowers (fertilized

\section{Genovesa}

January 1978

February--April 1978

July 1979

November 1978

$77.4(N=31)$
$81.8(N=22)$
$81.8(N=11)$
80

$39.6 \pm 5.7(N=24)$

$24.4 \pm 6.1(N=18)$

$63.8 \pm 12.2(N=11)$

$-$

I. Daphne

December 1977

$90.0(N=10)$

$94.9 \pm 11.5$

46.4

44.0

Consequences of Stigma Snipping to the Finches. We tested the possibility that the removal of stigmas has a signal function, altering the likelihood that the flower will be visited by finches thereafter, with data from an all day watch (19 December 1977) on 17 Opuntia echios flowers on Daphne. Of these 17 flowers all but 5 had their stigmas snipped, and of 56 visits by $G$. scandens all but 2 were by 4 uniquely color banded individuals. Due to either position of the bird or flower we saw the exact moment of stigma removal by banded birds at only 4 of these flowers. There were 32 subsequent visits by $G$. scandens to these flowers; 17 to 4 stigma snipped flowers, 15 to 5 intact flowers. Duration of visits to these stigma snipped and intact flowers were not significantly different $\left(t_{29}=1.19, P>0.2\right.$, two-tailed). We eliminated a visit terminated by a chase. There was also no difference in the number and duration $\left(t_{25}=0.05, P>0.2\right)$ of visits by $G$. fortis to stigma snipped and intact flowers. Carpenter bees visited stigma snipped and intact flowers 2 and 4 times respectively. There was no indication that visitation rates declined or increased immediately after snipping relative to the intact flowers. For example, snipped flowers received $0-1$ visit in the one hour following stigma removal and intact flowers at the same time in the morning received $0-1$ visit. Individuals that did the snipping returned as frequently to that flower ( $0-2$ visits) as they did to an intact flower ( $0-2$ visits) or to a flower that was snipped by others (0-3 visits). Another all day watch (30 January 1978) at flowers on Genovesa confirmed that the frequency of visits by $G$. conirostris, $G$. magnirostris, $G$. difficilis, Z. galapagoensis and $N$. parvulus, was unaffected by the stigma snipping from $G$. conirostris. Therefore there is no evidence that a flower with damaged or removed stigmas is perceived as an already visited flower by birds, who then alter their behavior accordingly.

\section{Discussion}

Opuntia depend on birds for pollination on islands lacking bees, and depend on mockingbirds (and possibly finches) for seed dispersal on islands lacking tortoises and iguanas (see also Racine and Downhower 1974). On all islands, the pollination of Opuntia is likely to be enhanced by birds. Whether or not the size of flowers, length of flowering season and amount and concentration of nectar produced are the result of evolution on the Galápagos cannot be determined without a knowledge of the ancestral species. Unfortunately there is considerable doubt about the most closely related species on the mainland (Dawson 1962, 1965; Anderson and Walkington 1967). A stronger case can be made for the evolution of seed size and hardness, of which there is an impressive variation among islands (Table 1), in par- tial response to the finches as seed predators; and the evolution of beak size and shape as adjustments to probing into Opuntia flowers and to the cracking of its seeds (Lack 1945, 1947; Bowman 1961, 1963; Abbott et al. 1977; Smith et al. 1978; Grant and Grant 1980a).

Thus to some extent finches and cactus have coevolved (cf. Ehrlich and Raven 1964). Although the details are different, there is a parallel between the finch cactus system and another more tightly linked, co-evolved system, that of figs and fig-wasps (Janzen 1979, Weibes 1979). A reproductive cost is borne by the plant in realizing a reproductive benefit. Can the Opuntia minimize this cost by preventing damage to its stigmas? Studies of other bird-visited plants are of little help in answering this question because pollen eating by birds appears to be rare, although perhaps not as rare as the scarcity of published reports would indicate, and because the stigma-snipping habit we have described appears to be unique. Nevertheless another polleneating bird, the brush-tongued lorikeet Glossopsitta porphyrocephala, removes pollen and nectar by a circular sweeping motion of its papillae-fringed tongue around a shallow cup-shaped eucalyptus flower without damaging the flowering parts (Churchill and Christenson 1970; Cleland 1969; Hopper and Burbidge 1979). Our observations of stigma snipping in cactus finches suggest a first destructive step (cf., Faegri and van der Pijl 1971) in the evolutionary development of a mutualistic association such as shown by lorikeets and eucalyptus. We first consider the habit of stigma snipping and then discuss its consequences and implications.

Why do finches snip stigmas? One answer is that the stigmas get in the way of the birds as they probe into the partially open flower for pollen and possibly nectar, so the birds remove them. Mockingbirds, which also probe into the flower do not snip stigmas. Their bills are perhaps too narrow and thin to be able to cut through the style, but more importantly their bills are $30 \%$ or more longer than the bills of $G$. conirostris on Genovesa and of G. scandens on Daphne. Therefore stigmas may not be an obstacle to mockingbirds. This argument implies that the height of style and stigmas corresponds approximately to the distance between bill tip and eye of the finches but is much shorter than that length in mockingbirds. Our measurements are consistent with this interpretation. The average length of style and stigmas in 20 flowers on Genovesa, sampled 2/bush, was $24.5 \pm 0.89 \mathrm{~mm}$. The average length from bill tip to leading edge of eye was $21.65 \pm 0.19$ for 36 adult $G$. conirostris and $34.70 \pm 0.13$ for 50 adult mockingbirds.

There may be less obvious benefits from the removal of stigmas. We tested and rejected two hypotheses; 1) that the birds 
used the removed stigmas as a signal to which they responded by altering their foraging behaviour, 2) that they gained an enhanced supply of nectar, either as total volume or amount of sugars. Since the stigmas are not eaten there is no nutritional benefit. We did not observe, or record on super-8 film, the finches ingesting any fluid from the damaged style that might enhance digestion of pollen. Therefore, by default, we accept the obstacle-removal hypothesis. The benefit to the birds appears to be increased foraging efficiency through easy access to pollen from the central incurving anthers, and to nectar if it is present (Fig. 1) at a time when alternative food is scarce and Opuntia pollen is being consumed by other bird species. Nectar taken either then or later in the day, may not only be a source of nutrition and moisture but it may also increase the digestion of pollen (Stanley and Linskens 1965; Gilbert 1972).

The obstacle-removal hypothesis implies a short term advantage, ease of pollen and nectar removal, over a potential long term disadvantage, the lack of seed set and fertile fruit formation which should be important to the finches later in the year. A potential cost is certainly present; stigma snipping eliminates or drastically reduces seed set. Is this cost really experienced by the birds?

There would be no diminished seed set overall if Opuntia plants compensated for seed loss by producing more flowers or by keeping their flowers open longer after they had lost their stigmas, thereby achieving more successful pollen donation to pollinators and enhanced seed set at other flowers. We have no data on the first possibility. It seems unlikely because flowering increased without the stimulus of stigma snipping during the wet season on Genovesa. However, the unanswered question is whether flower production is affected by stigma snipping in the dry season. We tested and rejected the second hypothesis, that flowers stay open longer and receive more visitors if their stigmas are removed. Moreover, all pollen is removed from flowers regardless of whether stigmas are snipped or not. Therefore we conclude that probably overall seed set is really diminshed as a result of stigma snipping, and birds in general experience a loss of food as a result.

The important question to ask is this; do the individuals which snip the stigmas experience a higher probability of dying in the dry season, when most of the annual mortality occurs (Smith et al. 1978; Grant and Grant 1980a, b), than do individuals which do not remove the stigmas? We have no evidence from our study of banded birds on Genovesa and Daphne that birds which were known to snip stigmas suffered a higher mortality in the dry season than those which were not known to snip stigmas. Moreover, the following considerations make differential mortality unlikely. Although all adults but especially male $G$. conirostris on Genovesa occur on their breeding territories in the (nonbreeding) dry season, and feed on the seeds in the fruits formed in or before the breeding season, they make longer and more frequent feeding trips outside the territories in the dry season than in the wet season. Therefore they are not entirely dependent upon the resources within their territories, nor do they have sole possession of them because mockingbirds do not respect the boundaries of $G$. conirostris territories and are usually dominant to individual $G$. conirostris at the fruits. As a result, refraining from stigma-snipping on a particular territory is not an assurance of a good food supply in the dry season for the owner. It might even encourage frequent intrusions from birds which cannot be repelled.

Thus there is no detectable selective penalty to individuals which exhibit a habit that has a short term benefit but a potential long term disadvantage that is experienced by all members of the population. We would expect this disadvantage to be particularly severe in drought years. Low, arid islands like Genovesa and Daphne can expect at least one drought year per decade (Grant and Boag 1980). During drought years there is very little primary and secondary production, although Opuntia still flowers and fruits in these years (Grant and Grant 1980 b) and its seed set is not known to be diminished. In a drought year we anticipate that stigma snipping will continue throughout the Opuntia flowering season because of a lack of alternative food items. On Genovesa in 1980 rains came 3 weels later than in 1978 , and cessation of stigma snipping was likewise delayed 3 weeks when it dropped from $43 \%(n=300)$ in the previous 3 weeks to $5 \%(n=100)$ in the week following the rains. So few flowers would be fertilized that the fruit supply later in the year might be severely limiting. For example at the end of a drought year on Daphne in 1977 Opuntia echios seeds were $20 \%$ of what they were at the end of 1973 and the population of $G$. scandens had declined to 38 per cent of previous numbers (Grant and Grant 1980 b). A second drought year with continued high levels of stigma snipping could so severely limit the seed supply that a population of $G$. scandens on a small island such as Daphne would be in jeopardy, particularly as $G$. scandens relies heavily on Opuntia seeds (Table 2) in the dry season prior to Opuntia flowering in October.

If our interpretations are correct, they carry a non-obvious but important implication. A widespread behavioral habit such as stigma snipping that gives a short-term benefit to the individual may increase the chances of the population going extinct in a drought year, or in the second of two successive drought years. This holds regardless of whether the trait has a genetic basis or not; other studies of manipulative behaviors in birds suggest a non-genetic or cultural transmission of such traits (e.g. Fisher and Hinde 1948, Norton-Griffiths 1969). It also holds regardless of whether or not the individuals that do the snipping have a greater chance of dying than those that do not. Stigma snipping may have contributed to the hitherto puzzling extinction of G. scandens on I. Pinzon this century (Grant and Boag 1980, Harris 1973).

Acknowledgments. This study was supported by NSF (DEB77-23377) We thank M. Kinnaird, P. Wellington, T.C. Will, N. Grant and K.T. Grant for field assistance, T.E. Moore, J.M. Kingsolver, R. Snelling and C.A. Triplehorn for help with insect identification. We thank I Abbott, D. deSteven, J.H. Myers, T.D. Price, D. Schluter, and J.N.M. Smith for reading the manuscript and F.B. Gill, D. Inouye, L. Wolf and an anonymous reviewer for valuable comments. C. Macfarland, H. Hoeck and the staff at the Charles Darwin Research Station provided logistical support.

\section{References}

Abbott I, Abbott LK, Grant PR (1977) Comparative ecology of Galápagos ground finches (Geospiza Gould): evaluation of the importance of floristic diversity and interspecific competition. Ecological Monographs 47:151-184

Anderson EF, Walkington DL (1967) A Study of some neotropical Opuntias. Summary of MS in library of Charles Darwin Research Station, Galápagos

Arp GK (1971) The Galápagos Opuntias: Another Interpretation. University of Colorado Museum, unpublished manuscript

Baker HG (1975) Sugar concentrations in nectars from hummingbird flowers Biotropica 7:37-41

Bowman RI (1961) Morphological differentiation and adaptation in the Galapagos finches. University of California. Berkeley, Publication in Zoology 58:1-302 
Bowman RI (1963) Evolutionary patterns in Darwin's finches. Occasional Papers California Academy of Sciences 44:107-140

Bowman RI, Carter A (1970) Egg-peaking behavior in Galapagos mockingbirds. Living Bird 9:243-270.

Carpenter FL (1976) Plant-pollinator interactions in Hawaii: pollination energetics of Metrosideros collina (Myrtaceae). Ecology $57: 1125-1144$

Churchill DM, Christensen P (1970) Observations and pollen harvesting by brush-tongued lorikeets. Australian Journal of Zoology $18: 427-437$

Cleland JB (1969) Lorikeets and the flowering of eucalypts. South Australian Ornithology 25:106-107

Dawson EY (1962) Cacti of the Galápagos Islands and coastal Ecuador. Cactus and Succulent Journal 34:67-74, 99-105

Dawson EY (1965) Further studies of Opuntia in the Galápagos Archipelago. Cactus and Succulent Journal 37:135-148

Dawson EY (1966) Cacti in the Galápagos Islands with special reference to their relations with Tortoises. In: Bowman RI (ed). The Galápagos. Proceedings of the Symposia of the Galápagos International Scientific Project. Univ California Press, Los Angeles, p 209 214

Ehrlich PR, Raven PH (1964) Bufferflies and plants: a study in coevolution. Evolution 18:586-608

Faegri K, Van der Pijl L (1971) Principles of Pollination Ecology. Pergamon Press, Oxford

Fisher J, Hinde RA (1948) The opening of milk bottles by birds. British Birds 42:347-357

Gilbert LE (1972) Pollen feeding and reproductive biology of Heliconius butterflies. Proceedings of the National Academy of Sciences USA 69:1403-1407

Grant BR, Grant PR (1979) Darwin's finches: Population variation and sympatric speciation. Proceeding of the National Academy of Sciences USA 76:2359-2363

Grant PR, Boag PT (1980) Rainfall on the Galápagos and the demography of Darwin's Finches. Auk 97:227-244

Grant PR, Grant BR (1980a) The breeding and feeding characteristics of Darwin's Finches on Isla Genovesa, Galápagos. Ecologica1 Monographs 50:381-410

Grant PR, Grant BR (1980b) Annual variation in finch numbers, foraging and food supply on Isla Daphne Major, Galápagos. Oecologia (Berl) 46:55-62
Grant PR, Grant KT (1979) Breeding and Feeding Ecology of the Galápagos dove Zenaida galapagoensis Condor 81:397-403

Harris MP (1973) The Galápagos avifauna. Condor 75:265-278

Hopper SD, Burbidge AA (1979) Feeding behaviour of a PurpleCrowned Lorikeet on flowers of Eucalyptus buprestium. Emu $79: 40-42$

Janzen DH (1979) How to be a Fig. Annual Reviews of Ecology and Systematics $10: 13-51$

Lack D (1945) The Galápagos finches (Geospizinae): A study in variation Occasional Papers of the California Academy of Sciences $21: 1$ 159

Lack D (1947) Darwin's finches. University Press, Cambridge. England

Linsley EG (1966) Pollinating Insects of the Galápagos Islands. In: Bowman RI (ed) The Galápagos Proceedings of the Symposia of the Galápagos International Scientific Project. Univ California Press, Los Angeles, p 225-232

Norton-Griffiths MN (1969) The organisation, control and development of paternal feeding in the oystercatcher (Haematopus ostralegus). Behaviour 34:55-114

Orr RT (1966) Evolutionary Aspects of the Mammalian Fauna of the Galápagos. In: Bowman RI (ed) The Galápagos Proceedings of the Symposia of the Galápagos International Scientific Project. Univ California Press, Los Angeles, p 276-281

Racine CH, Downhower JF (1974) Vegetation and reproductive strategies of Opuntia (Cactaceae) in the Galápagos islands. Biotropica $6: 175-186$

Rick CM (1966) Some Plant-Animal Relationships on the Galápagos Islands. In: Bowman RI (ed) The Galápagos Proceedings of the Symposia of the Galápagos International Scientific Project. Univ California Press, Los Angeles, p 215-224

Smith JNM, Grant PR, Grant BR, Abbott IJ, Abbott LK (1978) Seasonal variation in feeding habits of Darwin's ground finches. Ecology 59:1137-1150

Stanley RG, Linskens HT (1965) Protein diffusion from germinating pollen. Physiologia Plantarum 18:47-53

Wiggins IL, Porter DM (1971) Flora of the Galápagos Islands. Univerversity Press, Stanford, California, USA

Wiebes JT (1979) Co-evolution of figs and their insect pollinators. Annual Reviews of Ecology and Systematics 10:1-12

Received January 7, 1981 


\title{
The Population Ecology of a Natural Population of the Pierid Butterfly Colias alexandra
}

\author{
Jane Leslie Hayes* \\ Department of Entomology, University of Kansas, Lawrence, Kansas 66045, USA and \\ The Rocky Mountain Biological Laboratory, Crested Butte, Colorado 81224, USA
}

Summary. Key factor analysis techniques were used to examine factors determining the abundance of a population of non-pest Colias. The number of individuals entering each successive life stage in the sample population are summarized in life tables for 1975 to 1979 . Survivorship to the adult is a relatively consistent proportionality $(\bar{x}=1.2 \%$, S.D. $=1.14 ; 1975-1979)$. Factors resulting in reduced natality and, less importantly, mortality during larval diapause determine the population trends for $C$. alexandra. Egg mortality, pre-diapause larval mortality and postdiapause mortality contribute little to these trends. Possible key sources contributing to reduced natality are examined. Mortality of adults (including removal by collectors), poor weather conditions during the oviposition period, unseasonal snow or drought which affect nectar sources or oviposition sites are among the factors which cause reduced natality and result in population depression.

\section{Introduction}

Insects have proven to be useful vehicies for the study of natural populations. These animals meet several of the important criteria for successful long term observations of populations: they are numerous, relatively short-lived and sedentary, and visible. Butterflies, among the most visible insects, have been important tools for the study of evolutionary theory (e.g., mimicry, polymorphism, etc.), yet few data exist about factors that limit or regulate butterfly populations (cf. Gilbert and Singer 1975). Notably few life tables have been constructed for butterflies (e.g., Pieris rapae, Dempster 1967; Richards 1940; and Harcourt 1966; Lycaena dispar, Duffey 1968), although demographic models have been applied to numerous other insect species. However, adult butterflies have been the focus of the more extensive population studies (e.g., Ehrlich 1965; Ehrlich and Gilbert 1973; Brussard and Ehrlich 1970; Brussard et al. 1974; Gilbert and Singer 1973; Watt et al. 1977, 1979). The primary thrust of these studies has been to reveal the structure of adult populations which as Watt et al. (1977) point out "may themselves be adjusted by natural selection" and may be decisively important for the understanding of the population's ecology. Nevertheless, crucial to the complete understanding of the dynamics of a population is the determination of its demographic attributes. These attributes reflect the adaptations of the individual: its ability to procure resources, survive climatic extremes, avoid predators,

* - Present address: Department of Zoology, University of California, Davis, California 95616, USA etc. Insight into the causes of population fluctuation can be obtained when life tables can be coupled with an understanding of predation, parasitism, climate and other conditions that affect population numbers.

The sulfur butterflies (Colias, Pieridae) have been employed as model systems for the study of an extensive array of important ecological and evolutionary questions (e.g., Watt 1968; Hoffmann 1973; Taylor 1972; Silberglied and Taylor 1973; Grula and Taylor 1979 ; etc.). Knowledge of the population ecologies of members of this group is essential for the full understanding of their adaptive mechanisms and should contribute valuable insight to our understanding of natural populations of organisms in general.

This paper describes the results of a study of the factors determining the abundance of a natural population of Colias alexandra Edwards, a non-pest species of sulfur butterfly (Pieridae), which occurs in the Central Colorado Rockies. The study is concerned with the identification of the demographic attributes of this species and the environmental factors which interact with it, through the construction of life tables and the use of key factor analysis.

\section{Methods and Materials}

\section{The Organism}

Colias alexandra, first described by Edwards in 1873, is native to the Rocky Mountains and intermontane regions, flying in montane meadows from an elevation of approximately $1,800 \mathrm{~m}$ to timberline. The taxonomy and distribution of the C. alexandra complex are discussed in detail by Brown (1973) and Ferris (1973). Various other aspects of $C$. alexandra and ecology are described elsewhere (Ellis 1973; Watt et al. 1974, 1977; Hayes 1980a, b).

The population examined for this study is univoltine and utilizes Lathyrus leucanthus Rybd. as a larval foodplant. In this population, females begin ovipositing, eggs are laid singly on the dorsal surfaces of foodplant leaves in early July and continue through early August. Overwintering as diapausing third instar larva, there are two larval molts prior to the onset of winter. There are two post-diapause larval molts and the fully developed fifth instar larvae pupate in mid-June [a developmental timetable and more complete description of the biology and behavior of the developmental stages are presented by Hayes (1980a)]. Males typically appearing first (Watt et al. 1977), eclosion occurs in late June to early July. The adults, and to a lesser extent the developmental stages, occur concomitantly with other Colias species in this area; C. scudderi, C. eriphyle, and C., eurytheme.

\section{The Study Site}

A relatively large population of $C$. alexandra occurs in the neighborhood of the Rocky Mountain Biological Laboratory (3,200 m), near 
Table 1. Age-Specific Life Table for Colias alexandra (1975-1979)

\begin{tabular}{|c|c|c|c|c|}
\hline 1975 & $\begin{array}{l}\text { Number } \\
\text { entering } \\
\text { each stage }\end{array}$ & $\begin{array}{l}\text { Number } \\
\text { dying }\end{array}$ & $\%$ dying & $\begin{array}{l}\% \text { initial } \\
\text { number } \\
\text { (accumulated) }\end{array}$ \\
\hline egg: & 68 & & & \\
\hline infertility & & 5 & 7.4 & \\
\hline failure to hatch & & 2 & 2.9 & \\
\hline \multirow[t]{2}{*}{ miscellaneous } & & 19 & 27.9 & \\
\hline & & & 38.2 & 38.2 \\
\hline 1st instar: & 42 & & & \\
\hline earty & & 3 & 7.1 & \\
\hline \multirow[t]{2}{*}{ unknown } & & $\begin{array}{r}16 \\
3\end{array}$ & $\begin{array}{r}38.1 \\
7.1\end{array}$ & \\
\hline & & & 52.3 & 70.6 \\
\hline 2nd instar: & 20 & & & \\
\hline early & & 4 & 20.0 & \\
\hline late & & 2 & 10.0 & \\
\hline \multirow[t]{2}{*}{ unknown } & & 6 & 30.0 & \\
\hline & & & 60.0 & 88.2 \\
\hline 3rd instar: & 8 & 4 & 50.0 & 94.1 \\
\hline Diapause: & 4 & 2 & 50.0 & 97.1 \\
\hline Post-diapause: & 2 & & & \\
\hline 4th instar & & 0 & & \\
\hline $\begin{array}{l}\text { 5th instar } \\
\text { pupa }\end{array}$ & & & 0.0 & 97.1 \\
\hline Adult: & 2 & & & \\
\hline 1976 & $\begin{array}{l}\text { Number } \\
\text { entering } \\
\text { each stage }\end{array}$ & $\begin{array}{l}\text { Number } \\
\text { dying }\end{array}$ & $\%$ dying & $\begin{array}{l}\% \text { initial } \\
\text { number } \\
\text { (accumulated) }\end{array}$ \\
\hline egg: & 181 & & & \\
\hline infertility & & 12 & 6.6 & \\
\hline failure to hatch. & & 9 & 5.0 & \\
\hline \multirow[t]{2}{*}{ miscellaneous } & & 52 & 28.7 & \\
\hline & & & 40.3 & 40.3 \\
\hline 1st instar: & 108 & & & \\
\hline early & & 14 & 13.0 & \\
\hline late & & 14 & 13.0 & \\
\hline \multirow[t]{2}{*}{ unknown } & & 12 & 11.1 & \\
\hline & & & 37.1 & 62.4 \\
\hline 2nd instar: & 68 & & & \\
\hline early & & 0 & 0.0 & \\
\hline late & & 6 & 8.8 & \\
\hline \multirow[t]{2}{*}{ unknown } & & 26 & 38.2 & \\
\hline & & & 47.0 & 80.1 \\
\hline 3rd instar: & 36 & 14 & 38.9 & 87.8 \\
\hline Diapause: & 22 & 21 & 95.5 & 99.4 \\
\hline Post-diapa use: & 1 & & & \\
\hline 4th instar & & 0 & & \\
\hline $\begin{array}{l}\text { 5th instar } \\
\text { pupa }\end{array}$ & & & 0.0 & 994 \\
\hline Adult: & 1 & & & \\
\hline
\end{tabular}

Crested Butte, Gunnison Co., Colorado. This population occupies fescue grassland/sagebrush habitats of the East River Valley as characterized by Langenheim (1962).

In order to accumulate information on the numbers and survivorship of $C$. alexandra during the developmental stages, study plots
Table 1 (continued)

\begin{tabular}{|c|c|c|c|c|}
\hline 1977 & $\begin{array}{l}\text { Number } \\
\text { entering } \\
\text { each stage }\end{array}$ & $\begin{array}{l}\text { Number } \\
\text { dying }\end{array}$ & $\%$ dying & $\begin{array}{l}\% \text { initial } \\
\text { number } \\
\text { (accumulated) }\end{array}$ \\
\hline egg: & 371 & & & \\
\hline infertility & & 20 & 5.4 & \\
\hline failure to hatch & & 12 & 3.2 & \\
\hline miscellaneous & & 112 & 30.2 & \\
\hline & & & 38.8 & 38.8 \\
\hline 1st instar: & 227 & & & \\
\hline early & & 49 & 21.6 & \\
\hline $\begin{array}{l}\text { late } \\
\text { unknown }\end{array}$ & & $\begin{array}{r}43 \\
5\end{array}$ & $\begin{array}{r}18.6 \\
2.2\end{array}$ & \\
\hline & & & 42.7 & 65.0 \\
\hline 2nd instar: & 134 & & & \\
\hline early & & 18 & 13.4 & \\
\hline late & & 27 & 20.2 & \\
\hline \multirow[t]{2}{*}{ unknown } & & 1 & 0.8 & \\
\hline & & & 34.4 & 77.4 \\
\hline 3rd instar: & 87 & 55 & 63.2 & 92.4 \\
\hline Diapause: & 32 & 26 & 81.3 & 98.4 \\
\hline $\begin{array}{c}\text { Post-diapause: } \\
\text { 4th instar }\end{array}$ & 6 & 3 & & \\
\hline $\begin{array}{l}\text { 5th instar } \\
\text { pupa }\end{array}$ & & & 50.0 & 99.2 \\
\hline Adult: & 3 & & & \\
\hline
\end{tabular}

were established in an area $13 \mathrm{~km}$ southeast of Crested Butte, Gunnison Co., along Brush Creek, elevation $2,810 \mathrm{~m}$, where the adults and larval foodplant occur in relative abundance. The vegetation within each plot was representative of the area and was searched thoroughly for C. alexandra eggs and larvae. Plants with eggs or larvae were marked with numbered flags. The nutritional needs of a pre-diapause larvae are usually met by the original plant. Thus, individuals could be followed to diapause by marking the location of the host plant. The survivorship, developmental rates, and activities of each egg or larva were recorded regularly at 48 to $72 \mathrm{~h}$ intervals throughout the season. In 1976 , a permanent $20 \times 20 \mathrm{~m}$ enclosure was established. This area was protected from grazing cattle by erecting a three-strand barbed wire fence. The area surveyed was 200 square meters and was searched systematically in ten, $1 \times 20 \mathrm{~m}$ strips.

\section{Foodplant Sampling}

Samples of the larval host plant, L. leucanthus (1976-1979), and a close relative, $V$. americana (1978), were taken from the area surrounding the study site at regular intervals over the growing season (approximately once a week) and moisture content assessed as a measure of host plant quality. Three to ten grams of undamaged leaves of all sizes were removed from the plant stems, weighed, dried for over $48 \mathrm{~h}$ at $100^{\circ} \mathrm{C}$ and subsequently reweighed.

\section{Data Analysis}

Age-specific or horizontal life tables were constructed for each year from 1975 to 1979. The life table data were analyzed by key-factor analysis techniques (Varley and Gradwell 1960). k, key or killing factor is a concept originally introduced by Haldane (1949) and applied by Morris (1958) and Varley and Gradwell (1960) to statistical methods for identifying the age-specific cause of population change. The $\mathrm{k}$-value for the mortality of each life stage is the difference between the common logarithms of the number entering that stage and the subsequent one. The total generation mortality is calculated by adding all the $\mathrm{k}$-values. The k-values for each life stage over a number of generations are plotted against time. The total generation mortality caused entirely 